UDK 613.88:37.016

Pregledni rad

Primljeno: 26.2.2021.

\author{
Lucija TOMAC \\ Rijeka, Hrvatska, Itomac@ffri.hr
}

\title{
HOLIZAM ILI CENZURIZAM? KOMPARATIVNA ANALIZA KURIKULA ČETVRTOG MODULA ZDRAVSTVENOG ODGOJA
}

Sažetak Rad se bavi komparativnom analizom kurikula četvrtog modula Zdravstvenog odgoja pod nazivom Spolna/rodna ravnopravnost $i$ odgovorno spolno ponašanje, koji je na snazi bio u školskoj godini 2012./2013. i kurikula međupredmetne teme Zdravlje, koji je na snagu stupio 2019. godine. Rad problematizira razliku u koncepcijama kurikula, koja uključuje modularnu konceptualizaciju Zdravstvenog odgoja i međupredmetnu obradu teme Zdravlje. Sadržajna analiza kurikula pokazala je da se oba kurikula mogu kategorizirati u Tip 3 programa seksualne edukacije iako kurikul Spolne/rodne ravnopravnosti $i$ odgovornog spolnog ponašanja predstavlja bolji primjer Tipa 3. Također, sadržajna analiza argumentirala je ubrajanje kurikula međupredmetne teme Zdravlje u generaciju proširenih programa, dok je kurikul Spolne/ rodne ravnopravnosti i odgovornog spolnog ponašanja pripao generaciji teorijski utemeljenih programa. Analiza je pokazala evidentan nedostatak rodnih tema u međupredmetnoj temi Zdravlje, koje čine jednu od temeljnih karakteristika cjelovite seksualne edukacije, kao i dominantnu usmjerenost na tjelesne aspekte seksualnosti. U slučaju Spolne/rodne ravnopravnosti i odgovornog spolnog ponašanja tematika ovog tipa je zastupljenija i čini ga boljim primjerom kurikula koji teži istinskoj cjelovitoj seksualnoj edukaciji.

Ključne riječi: cjelovita seksualna edukacija; četvrti modul; međupredmetna tema Zdravlje; Spolna/rodna ravnopravnost i odgovorno spolno ponašanje; Zdravstveni odgoj

\section{HOLISM OR CENSORSHIP? \\ COMPARATIVE ANALYSIS OF THE CURRICULUM OF THE FOURTH MODULE OF HEALTH EDUCATION}

\begin{abstract}
The paper deals with a comparative analysis of the curriculum of the fourth module of Health Education called Gender Equality and Responsible Sexual Behavior, which was in force in the school year 2012/2013. and the curriculum of the cross-curricular topic Health, which came into force in 2019. The paper problematizes the difference in curriculum conceptions, which includes modular conceptualization of Health Education and interdisciplinary treatment of Health topics. The content analysis of the curriculum showed that both curricula can be categorized in Type 3 of sex education programs, although the curriculum of Gender Equality and Responsible Sexual Behavior is a better example of Type 3. Also, the content analysis argued the purpose of setting the curriculum of Gender Equality and Responsible Sexual Behavior into the generation of theoretically based programs. The analysis showed an evident lack of gender topics in the cross-curricular topic Health, which is one of the basic characteristics of holistic sex education as well as a dominant focus on the physical aspects of sexuality. In the case of Gender Equality and Responsible Sexual Behavior, this type of topic is represented and makes it a better example of a curriculum that strives for true holistic sexual education. Keywords: Comprehensive sex education; Fourth module; Cross-curricular topic Health; Gender equality and responsible sexual behavior; Health education
\end{abstract}




\section{Uvod}

Seksualna edukacija jedno je od kritičnih područja obrazovanja i socijalne politike. Legalni, financijski i praktični aspekti seksualne edukacije oblikovani su socijalnim i političkim pogledima svake države, što dovodi do velikog spektra načina i kvalitete provedbe seksualne edukacije u zemljama članicama Europske unije (EP, 2013). Važno je naglasiti kako dominantan diskurs provođenja (i uvođenja) seksualne edukacije ovisi o utjecaju ključnih društvenih i političkih aktera. Kako bi se iskazala važnost i reguliralo provođenje seksualne edukacije na razini Europske unije, donesene su smjernice koje pokušavaju ujednačiti njezinu kvalitetu na razini svih zemalja članica. Neki od tih dokumenata uključuju Međunarodne smjernice seksualne edukacije (UNESCO, 2009a), Standarde spolnog odgoja u Europi (BZgA, 2010), Nacionalne tehničke smjernice seksualne edukacije (UNESCO, 2018) i mnoge druge koji na nadnacionalnoj razini pokušavaju pružiti valjane argumente i znanstveno utemeljene okvire za provedbu seksualne edukacije. Smjernice i standardi polaze od činjenice da je seksualnost fundamentalan aspekt ljudskog života, čija je temeljna karakteristika različitost zbog čega se ne može razumjeti bez spominjanja roda, ali i kulturalnog utjecaja koji propisuje koja su ponašanja prihvatljiva (UNESCO, 2009b). Cilj svakog kurikula seksualne edukacije prvenstveno treba težiti osnaživanju djece i mladih znanjem, vještinama, ponašanjima i vrijednostima koje će ih ojačati u shvaćanju svojeg zdravlja, blagostanja i dostojanstva. Kurikuli bi također trebali naglašavati važnost razvoja socijalnih i seksualnih veza temeljenih na poštovanju, prvenstveno putem poticanja učenika na razmišljanje o utjecaju odluka na njihovo, ali i tuđe blagostanje te razumijevanje i osiguravanje zaštite svojih prava kroz život (UNESCO, 2018). Programe razvijene u skladu s predloženim ciljevima, koji putem sadržaja ostvaruju predviđene ishode učenja o kognitivnom, emocionalnom, tjelesnom i socijalnom aspektu seksualnosti, naziva se programima cjelovite seksualne edukacije. Ovi programi obilježeni su kriterijima koji uključuju znanstvenu utemeljenost, postupnost, dobnu i razvojnu primjerenost, kurikul primjeren nastavnicima, cjelovitost koja nije usmjerena samo na tjelesni aspekt seksualnosti, temeljenost na ljudskim pravima i rodnoj jednakosti, kulturnu jednakost i prikladnost kontekstu, transformaciju u pogledu razvoja kritičkog mišljenja i razvijanje vještina potrebnih za donošenje zdravih odluka (UNESCO, 2018). 
Republika Hrvatska od svog osamostaljenja pokušala je u škole uvesti niz programa seksualne edukacije. Prvi program, TeenSTAR, sadržavao je radionice i predavanja o seksualnosti, koji su tvoj temelj pronalazili u učenjima Katoličke Crkve. Nakon TeenSTARA sredinom 2000-ih pojavljuje se program $M E M O A I D S$, namijenjen prvenstveno prevenciji zaraze HIV-om. Zbog toga što Ministarstvo znanosti, obrazovanja i sporta nije odobravalo prva dva programa sve do školske godine 2012./2013. sadržaji seksualne edukacije nisu bili predviđeni u školskim kurikulima. Pomak u uvođenju seksualne edukacije u osnovnoškolsko i srednjoškolsko obrazovanje trebao se pokazati implementacijom Zdravstvenog odgoja - koncepta sastavljenog u četirima modulima, koji se bavi zdravim životom, prevencijom ovisnosti, prevencijom nasilničkog ponašanja i spolnom/rodnom ravnopravnošću. Četvrti modul Zdravstvenog odgoja - Spolna/rodna ravnopravnost i odgovorno spolno ponašanje obuhvaćao je teme istoimenog sadržaja, no zbog zahtjeva dijela građanstva, na čelu s udrugama GROZD i REFORMA, Ustavni sud je ukinuo njegovo provođenje. Nakon nekoliko godina mirovanja i zanemarivanja Zdravstvenog odgoja 2019. godina rezultirala je Odlukom o donošenju kurikula za međupredmetnu temu Zdravlje za osnovne i srednje škole u Republici Hrvatskoj. Međupredmetna tema Zdravlje provodi se kroz tri domene integrirane u postojeće obvezne predmete, a uključuje tjelesno, mentalno i socijalno zdravlje te pomoć i samopomoć. Od ukidanja četvrtog modula Zdravstvenog odgoja do donošenja odluke o donošenju kurikula međupredmetne teme Zdravlje proteklo je šest godina. To je razdoblje koje je promijenilo pogled i fokus na određene sadržaje u kontekstu zdravlja učenika (posebice njihove seksualne edukacije).

Upravo je zato cilj ovog rada provesti komparativnu analizu kurikula četvrtog modula Zdravstvenog odgoja pod nazivom Spolna/rodna ravnopravnost $i$ odgovorno spolno ponašanje i kurikula međupredmetne teme Zdravlje za osnovne i srednje škole iz perspektive cjelovite seksualne edukacije. Svrha ovog rada je prikazati razliku u konceptima koji teže seksualnoj edukaciji učenika na području Republike Hrvatske. Analizom tematskih područja, ishoda učenja i koncepcije programa koji predstavljaju pokušaj seksualne edukacije pružit će se uvid u ključne sličnosti i razlike posljednjih dvaju programa koja su se provodila u Republici Hrvatskoj. Sadržajnom analizom pokušat će se odgovoriti na sljedeća pitanja: 
- Koje su sličnosti i razlike u konceptima programa Spolna/rodna ravnopravnost $i$ odgovorno spolno ponašanje i međupredmetne teme Zdravlje?

- Na koji način oba analizirana kurikula obrađuju slične tematske sadržaje?

- Postoji li različitost u pojavnosti određenih sadržaja u analiziranim kurikulima i na koji način se ona manifestira?

\section{Usporedba konceptualizacije kurikula}

prema Standardima spolnog odgoja u Europi (BZgA, 2010) postoje tri kategorije programa seksualne edukacije. Tip 1 predstavlja programe koji se primarno ili jedino usredotočuju na suzdržavanje od spolnog odnosa prije braka i poznati su kao apstinencijski programi. Tip 2 obuhvaća programe koji suzdržavanje (od seksualnog odnosa) sadrže kao mogućnost, ali istovremeno pažnju posvećuju i sprječavanju začeća i provođenja sigurnog seksa. Zadnji tip programa, Tip 3 sadrži elemente Tipa 2, ali ih postavlja u širu perspektivu osobnog i spolnog rasta, čime ovaj tip dobiva naziv holističkog spolnog odgoja (BZgA, 2010). U slučaju Republike Hrvatske, četvrti modul Zdravstvenog odgoja pod nazivom Spolna/rodna ravnopravnost i odgovorno spolno ponašanje može se svrstati u program Tipa 3 jer osim tjelesnog aspekta seksualnosti, obuhvaća rodne teme i teme usmjerene na razvoj cjelovite i odgovorne ličnosti pojedinca koja pažnju usmjerava na svoje i tuđe reproduktivno i općenito zdravlje. Predviđen je kao jedan od modula Zdravstvenog odgoja, čiji će se sadržaj obrađivati kao dodatni, uz povremenu integraciju u obavezne predmete osnovnih i srednjih škola. S druge strane, međupredmetna tema Zdravlje, kao što joj govori i ime, nije predviđena kao poseban modul poučavanja, nego sadrži implikacije za integraciju u postojeće predmete i međupredmetnu obradu. Ovaj program isto bi se ugrubo mogao svrstati u Tip 3 iako u mnogo manjoj mjeri od četvrtog modula Zdravstvenog odgoja. Razlog zašto je međupredmetna tema Zdravlje manje pogodna kategorizaciji u Tip 3 leži u činjenici nedostatka rodne tematike i fokusa većinom na tjelesni aspekt seksualnosti. Međupredmetna tema Zdravlje obrađuje problematiku poput nasilja i komunikacije, no zadržava je na općenitoj razini, rijetko se dotičući njezine problematike u kontekstu 
seksualnosti. Kako bi se povukla bolja paralela između ovih dvaju programa, može se upotrijebiti klasifikacija pet generacija programa seksualne edukacije koja obuhvaća informativne programe, proširene programe, prevencijske HIV/AIDS programe, apstinencijske programe i teorijski utemeljene programe (Štulhofer i Hodžić, 2003). Prema svojim karakteristikama modul Spolna/rodna ravnopravnost i odgovorno spolno ponašanje može se ubrojiti u teorijski utemeljene programe koji čine najnoviju generaciju seksualne edukacije, čija je osobitost utemeljenost na empirijski provjerenim modelima promjene ponašanja. Ovakvi programi nastoje potaknuti odgovorno iskazivanje seksualnosti kroz usvajanje specifičnih bihevioralnih ponašanja. Prema svom predmetu kurikul međupredmetne teme Zdravlje ne bi se mogao ubrojiti u generaciju teorijski utemeljenih programa. Bez obzira na njegovu znanstvenu utemeljenost koja se legitimira implementacijom u obvezne predmete, kurikul međupredmetne teme Zdravlje pogodniji je za klasifikaciju u generaciju proširenih programa. Ovi programi uključuju usvajanje vještina samostalnog odlučivanja, razvijanje komunikacijskih vještina te razjašnjavanje stavova i vrijednosti vezanih uz seksualnost. Problemi predmeta kurikula seksualne edukacije javljaju se uslijed nestandardizirane prakse provođenja i uvođenja školske seksualne edukacije na razini Europe s obzirom na činjenicu da predmet i razrada kurikula osciliraju ovisno o dominantnim diskursima. Također, programi su podložni promjenama ovisno o predmetima u sklopu kojih se obrađuju. Ako se seksualna edukacija provodi u okviru nastavnih predmeta poput Biologije ili tjelesnog odgoja, fokus će biti stavljen na tjelesne aspekte seksualnosti. S druge strane, ako se seksualna edukacija provodi u okviru društveno-humanističkih predmeta, veća pozornost bit će posvećena društvenim, interakcijskim i moralnim pitanjima (BZgA, 2010).

Nadalje, primarna razlika programa Spolna/rodna ravnopravnost i odgovorno spolno ponašanje i međupredmetne teme Zdravlje ogleda se u načinu koncipiranja kurikula. Kurikul međupredmetne teme Zdravlje predviđa ishode učenja podijeljene u pet ciklusa, dok je četvrti modul Zdravstvenog odgoja predviđenu tematiku obrađivao prema kriterijima razreda. Međupredmetna tema Zdravlje $\mathrm{u}$ prvi ciklus ubraja učenike prvog i drugog razreda osnovne škole. Drugi ciklus odnosi se na učenike trećeg, četvrtog i petog razreda osnovne škole. Učenici šestog, sedmog i osmog razreda smješteni su u treći ciklus. Na razini srednje 
škole provode se posljednja dva ciklusa. Četvrti ciklus namijenjen je učenicima prvog i drugog razreda četverogodišnjih i prvog razreda trogodišnjih škola. Posljednji, peti ciklus uključuje treći i četvrti razred četverogodišnjih te drugi i treći razred trogodišnjih srednjoškolskih programa. Suprotno od međupredmetne teme Zdravlje, Spolna/rodna ravnopravnost i odgovorno spolno ponašanje ne posjeduje cikluse, nego kategorizira predviđeni sadržaj prema kriteriju dobi i razreda koji učenici pohađaju. Također, Zdravlje je međupredmetna tema bez predviđenog broja sati, dok je Spolna/rodna ravnopravnost $i$ odgovorno spolno ponašanje koncept $\mathrm{s}$ razrađenim kriterijima integriranih i dodatnih sadržaja. Sukladno tome je li sadržaj integriran u postojeće predmete ili ga je predviđeno obrađivati kao dodatni četvrti modul, imao je razrađene sadržaje i specifičan broj sati dodijeljen svakoj od tema. Još jedna od temeljnih razlika očituje se u dobnoj razlici uvođenja seksualne tematike. U slučaju Spolne/rodne ravnopravnosti $i$ odgovornog spolnog ponašanja modul propisuje uvođenje od trećeg razreda osnovne škole, dok seksualnu tematiku međupredmetna tema Zdravlje počinje obrađivati od prvog razreda osnovne škole. Između ostalog, razlika se pronalazi i u završetku obrade tematike koja u četvrtom modulu Zdravstvenog odgoja staje u trećem razredu srednje škole, dok se u sklopu međupredmetne teme Zdravlje obrađuje sve do četvrtog razreda srednje škole.

Tablica 1. Usporedni prikaz ciklusa međupredmetne teme Zdravlje i modula Spolna/rodna ravnopravnost i odgovorno spolno ponašanje

\begin{tabular}{|c|c|c|c|}
\hline & \multicolumn{2}{|c|}{ međupredmetna tema Zdravlje } & $\begin{array}{c}\text { modul Spolna/rodna ravnopravnost } \\
\text { dogovorno spolno ponašanje }\end{array}$ \\
\hline 1. CIKLUS & \multicolumn{2}{|c|}{ 1. razred osnovne škole } & \\
\hline \multirow[t]{3}{*}{ 2. CIKLUS } & \multicolumn{2}{|c|}{ 3. razred osnovne škole } & 3. razred osnovne škole \\
\hline & \multicolumn{2}{|c|}{ 4. razred osnovne škole } & 4. razred osnovne škole \\
\hline & \multicolumn{2}{|c|}{ 5. razred osnovne škole } & 5. razred osnovne škole \\
\hline \multirow[t]{3}{*}{ 3. CIKLUS } & \multicolumn{2}{|c|}{ 6. razred osnovne škole } & 6. razred osnovne škole \\
\hline & \multicolumn{2}{|c|}{ 7. razred osnovne škole } & 7. razred osnovne škole \\
\hline & 8. razred osn & ne škole & 8. razred osnovne škole \\
\hline \multirow[t]{2}{*}{ 4. CIKLUS } & \multirow{2}{*}{\multicolumn{2}{|c|}{$\begin{array}{ll}\begin{array}{l}\text { 1. razred četverogodišnje } \\
\text { srednje škole }\end{array} & \begin{array}{l}\text { 1. razred trogodišnje } \\
\text { srednje škole }\end{array} \\
\begin{array}{l}\text { 2. razred četverogodišnje } \\
\text { srednje škole }\end{array} & \end{array}$}} & 1. razred srednje škole \\
\hline & & & 2. razred srednje škole \\
\hline 5. CIKLUS & $\begin{array}{l}\text { 3. razred četverogodišnje } \\
\text { srednje škole } \\
\text { 4. razred četverogodišnje } \\
\text { srednje škole }\end{array}$ & $\begin{array}{l}\text { 2. razred trogodišnje } \\
\text { srednje škole } \\
\text { 3. razred trogodišnje } \\
\text { srednje škole }\end{array}$ & 3. razred srednje škole \\
\hline
\end{tabular}

*praznine predstavljaju nedostatak tematike u 1. i 2. razredu osnovne škole i 4. razredu srednje škole 


\section{Sadržajna komparacija predmeta kurikula}

Kako bi usporedba kurikula međupredmetne teme Zdravlje (Odluka o donošenju kurikuluma za međupredmetnu temu Zdravlje za osnovne škole i srednje škole u Republici Hrvatskoj, NN 10/19) i modula Spolna/rodna ravnopravnost $i$ odgovorno spolno ponašanje (AZOO, 2012) bila prikladnija sadržajnoj analizi, tematika je analizirana prema ciklusnom konceptu kojemu teži međupredmetna tema Zdravlje. Zbog toga je sadržajna komparacija provedena iz perspektive pet ciklusa kroz koje se analiziraju teme i ishodi učenja u komparaciji s razrednim konceptom koji je bio prisutan u modulu Spolna/rodna ravnopravnost $i$ odgovorno spolno ponašanje.

\section{Prvi ciklus (1. i 2. razred osnovne škole)}

Prvi ciklus, predviđen za učenike prvog i drugog razreda osnovne škole, postoji u međupredmetnoj temi Zdravlje, ali ove dobno-razredne kategorije u četvrti modul nisu uključene. Iz domene tjelesnog zdravlja, međupredmetna tema Zdravlje fokusirana je na ishode poput opisivanja tjelesnih i osobnih razlika te sličnosti između dječaka i djevojčica. Domena mentalnog i socijalnog zdravlja naglasak stavlja na razlikovanje prijateljskih odnosa od onih koji to nisu, prepoznavanje nasilničkih oblika ponašanja, njegovih vrsta i postupaka nenasilnog rješavanja problema te opisivanja različitosti u ljudima.

\section{Drugi ciklus (3., 4., i 5. razred osnovne škole)}

Sličnosti u drugom ciklusu, namijenjenom učenicima trećeg, četvrtog i petog razreda osnovne škole, pronalaze se u obradi tematike puberteta i razvojnih problema u obama analiziranim kurikulima. Bez obzira na tematsku povezanost, nailazi se na značajne razlike.

Perspektiva obrade sadržaja povezanih s pubertetom u međupredmetnoj temi Zdravlje, iz domene tjelesnog zdravlja, teži ishodu učenja koji glasi „(učenik) objašnjava što je pubertet i koje promjene donosi“. Detaljnije, ovim se ishodom želi postići da učenik „opisuje razvoj ljudskoga tijela od začeća do puberteta, prepoznaje fiziološke varijacije u rastu i razvoju“ i „razlikuje pravilna pojašnjenja od pogrešnih tumačenja promjena i situacija koje prate pubertet". Iz domene mentalnog i socijalnog zdravlja, nakon obrade sadržaja predviđa se 
da učenik ,prepoznaje i opisuje razvojne promjene u sebi i drugima“, specifičnije ,objašnjava razvojne promjene koje se zbivaju prije ulaska i ulaskom u pubertet“, kao i „objašnjava razlike u individualnom razvoju“, razlikuje pojmove samopoštovanje i samopouzdanje (Odluka o donošenju kurikuluma za međupredmetnu temu Zdravlje za osnovne škole i srednje škole u Republici Hrvatskoj, NN 10/19). Spolna/rodna ravnopravnost $i$ odgovorno spolno ponašanje problematici puberteta pristupa iz drugog kuta koji teži ishodima poput „raspraviti što su stidljivost, zbunjenost i druge neugodne emocije koje se pojavljuju u pubertetu vezane uz fizičke promjene“, „prepoznati spolnost kao sastavni dio cjelokupnog čovjekova života“ i ,objasniti masturbaciju kao sastavni dio ljudske spolnosti (objasniti pogrešnost nekad raširenih vjerovanja o njezinoj štetnosti)“(AZOO, 2012). Iz ishoda učenja vidljivo je da međupredmetna tema Zdravlje naglasak stavlja većinom na tjelesni aspekt seksualnosti, dok četvrti modul teži prihvaćanju spolnosti kao dijela ljudskog života dotičući se i masturbacije kao njezinog legitimnog segmenta.

Spolna/rodna ravnopravnost i odgovorno spolno ponašanje obrađuje tematiku razlika rodnih uloga u društvu i obitelji te rodna očekivanja među vršnjacima u školi i medijima, koji se mogu pronaći u sljedećim ishodima učenja (AZOO, 2012):

- opisati razliku između spola i roda, odnosno bioloških karakteristika te društvenih očekivanja i normi

- prepoznati spolne/rodne stereotipe u medijima

- raspraviti kako mediji i internet stvaraju norme izgleda i ponašanja

- raspraviti što su stidljivost, zbunjenost i druge neugodne emocije koje se pojavljuju u pubertetu vezane uz fizičke promjene.

S druge strane, međupredmetna tema Zdravlje, slično kao i u prvom ciklusu, naglasak stavlja na vrste nasilja i načine nenasilničkog rješavanja sukoba. Osim navedenog, planirano je učenje o vrstama komunikacije, rad na procjeni vršnjačkih odnosa, pravu na izbor i usporedbu te podržavanje različitosti. Neki od ishoda učenja ovog modula su sljedeći (MZO, 2019):

- razlikovati verbalnu od neverbalne komunikacije 
- opisati neprimjerena vršnjačka ponašanja

- razlikovati vrste nasilja i postupke nenasilnog rješavanja sukoba.

Treći ciklus (6., 7. i 8. razred osnovne škole)

Treći ciklus, orijentiran učenicima šestog, sedmog i osnovnog razreda osnovne škole, u obama kurikulima sličnost pronalazi u obradi koncepcija komunikacije, vršnjačkog pritiska i emocija. Ipak, bez obzira na povezanost sadržaja, i u ovom dijelu kurikula mogu se pronaći značajne razlike.

U međupredmetnoj temi Zdravlje ishodi učenja teže poticanju učenika na razlikovanje i vrednovanje različitih načina komunikacije i ponašanja, opisivanju i procjeni vršnjačkog pritiska. Neki od ishoda učenja vezanih uz komunikaciju i vršnjački pritisak uključuju sljedeće (Odluka o donošenju kurikuluma za međupredmetnu temu Zdravlje za osnovne škole i srednje škole u Republici Hrvatskoj, NN 10/19):

- navesti i objasniti vrste pristanka u prijateljskim/partnerskim odnosima i načine kako im se oduprijeti

- razlikovati svoje od tuđih potreba, ponašanja, osobina i osjećaja

- povezati vrste ponašanja s mogućim posljedicama

- objasniti razlike između asertivnoga, pasivnoga i agresivnoga ponašanja

- obrazložiti svoju ulogu i doprinos u osnaživanju zajednice.

Slični ishodi pronalaze se i u temi Vršnjački pritisak, samopoštovanje i rizična ponašanja predviđenoj u Spolnoj/rodnoj ravnopravnosti i odgovornom spolnom ponašanju. Podudarnost između ovih dvaju kurikula pronalazi se u sljedećim ishodima Spolne/rodne ravnopravnosti i odgovornog spolnog ponašanja:

- prepoznati pritiske i rizične situacije u prijateljskim/partnerskim odnosima

- prepoznati i odbiti vršnjačke pritiske i neželjena ponašanja vezana uz spolnost. 
Ipak, već na kraju drugog ishoda vidljiv je naglasak na ponašanjima vezanim uz spolnost. Na drugi se ishod nadograđuju ishodi ,dati primjer i diskutirati o rizičnim spolnim ponašanjima“ i ,prepoznati i protumačiti ulogu niskog samopoštovanja u rizičnim spolnim ponašanjima“.

Asertivnost kao stečena sposobnost obrađuje se i okviru teme pod nazivom Važnost samopoštovanja, asertivnosti i osobnog integriteta za odgovorno odlučivanje za učenike osmog razreda u sklopu Spolne/rodne ravnopravnosti i odgovornog spolnog ponašanja. Ipak, kut gledišta ovog modula naglasak stavlja na izgradnju asertivnosti i raspravu zašto je ona važna u prevenciji seksualnih rizika. Također, navedena tema predviđa da će učenici izraziti i jačati osobni integritet bez obzira na popularnost, raspravljati o utjecaju medijskih poruka te izgraditi pozitivnu sliku o vlastitom tijelu.

Vezano uz problematiku emocija, koja je zajednička u obama analiziranim kurikulima, može se vidjeti da međupredmetna tema Zdravlje emocijama pristupa iz aspekta prepoznavanja utjecaja razvojnih promjena na emocije i prepoznavanju stresa kao važnog čimbenika u narušavanju mentalnog zdravlja. Osim navedenog, međupredmetna tema Zdravlje predviđa ishode u kojima će učenici prepoznati i objašnjavati svoje osobne i socijalne potencijale te prepoznati utjecaj odgovornog spolnog ponašanja na mentalno zdravlje.

Osim navedenih sličnosti, Spolna i rodna ravnopravnost $i$ odgovorno spolno ponašanje komunikaciji i vršnjačkim odnosima pristupa iz drugačije perspektive. Tema Emocije u vršnjačkim odnosima teži ishodima koji naglasak stavljaju na razlikovanje pojmova prijateljstva, zaljubljenosti, ljubavi, bliskosti i seksualne privlačnosti te raspravljanju o tome kako se stvaraju bliski odnosi između dviju osoba. Također, jedan od ishoda ove teme je i opisati neugodne emocije u odnosima s vršnjacima. Suštinska razlika između ovih dvaju kurikula uočljiva je u dubini rasprave o odnosima. Dok međupredmetna tema Zdravlje predviđa ishode na nižim razinama Bloomove taksonomije, Spolna/rodna ravnopravnost i odgovorno spolno ponašanje u ovom pogledu teži razvijanju promišljanja o stvaranju samih odnosa. Primjerice, Spolna/rodna ravnopravnost i odgovorno spolno ponašanje predviđa raspravljanje o stvarima koje privlače ljude, kako ljudi razumiju sami sebe i svoje potrebe te kako te iste potrebe izreći. Kao još jedna od razlika u pristupu ovoj temi može se izdvojiti i problematiziranje 
uloge medija u vršnjačkim odnosima koju je predviđao četvrti modul. Kroz obradu uloge medija u vršnjačkim odnosima modul Spolna/rodna ravnopravnost i odgovorno spolno ponašanje od učenika je očekivao postizanje sljedećih ishoda učenja (AZOO, 2012):

- navesti i raspraviti pozitivne i negativne primjere napisa o seksualnosti mladih u medijima

- prepoznati i raspraviti spolne/rodne stereotipe vezane uz seksualno ponašanje prisutne u medijima

- raspraviti način na koji pornografija prikazuje ljudsku seksualnost te muške i ženske seksualne uloge.

Iz navedenih ishoda moguće je uočiti tendenciju rasprave o marginalnim temama poput pornografije i gorućim temama o rodnim ulogama i stereotipima, koje ni na koji način nisu zastupljene u međupredmetnoj temi Zdravlje.

Još jedna od fundamentalnih razlika nalazi se i načinu pristupa seksualnim odnosima. Međupredmetna tema Zdravlje prepoznavanje važnosti brige o reproduktivnom zdravlju svela je u domenu tjelesnog zdravlja. Sukladno takvoj klasifikaciji, temeljni ishodi orijentirani su na prepoznavanje važnosti očuvanja reproduktivnog zdravlja i razgovora o reproduktivnom zdravlju s roditeljima, učiteljima i stručnjacima, ali i opisivanju gdje i kako zatražiti stručnu pomoć. U ovoj tematskoj cjelini modul Spolna/rodna ravnopravnost $i$ odgovorno spolno ponašanje poseban osvrt stavio je na odgovorno spolno ponašanje i rizike preranog stupanja u seksualne odnose. Kroz rad na temi odgovornog spolnog ponašanja za učenike je predviđena mogućnost definiranja odgovornog seksualnog ponašanja, vježbanje koraka donošenja odgovornih odluka, objašnjavanje što znači ,ne“ u komunikaciji o spolnosti te prepoznavanje i definiranje različitih oblika nasilnog seksualnog ponašanja. Kao temelj obrade ove teme javio se ishod raspraviti što znači biti seksualno biće i uključuje li to nužno seksualne odnose. Prerani seksualni odnosi problematizirani su kroz raspravljanje o rizicima preranog stupanja u spolne odnose te raspravljanje o pitanju odgađanja seksualnih odnosa i pojmu apstinencije. Tjelesna perspektiva, prisutna u međupredmetnoj temi Zdravlje u Spolnoj/rodnoj ravnopravnosti i odgovornom spolnom ponašanju, propisana je za obradu kao integrirani sadržaj u okviru 
Biologije se bavi temama poput roditelja i potomaka, srodnosti i raznolikosti, nespolnog i spolnog razmnožavanja, nasljeđivanja, građe i uloge spolnih organa, začeća i razvitka djeteta prije rođenja, blizanačkom trudnoćom, životnim razdobljima čovjeka i odgovornim spolnim ponašanjem.

Ciklus (1. i 2. razred četverogodišnje srednje škole/1. razred trogodišnje srednje škole)

Četvrti ciklus, odnosno tematske jedinice koje će obrađivati učenici prvog i drugog razreda četverogodišnje srednje škole i prvog razreda trogodišnje srednje škole, u obama se analiziranim kurikulima ponovno dotiču komunikacije. Osim komunikacije, oba kurikula bave se problematizacijom nasilja i odgovornog spolnog ponašanja.

Međupredmetna tema Zdravlje u kontekstu komunikacije progovara o odabiru primjerenih odnosa i komunikacije te o nasilju, izbjegavanju i rješavanju sukoba. Naglasak je stavljen na razlikovanje i procjenjivanje dobronamjernosti komunikacije i ponašanja u stvarnom i virtualnom svijetu te na analizu vrste i uzroka nasilja i obrazlaganje načina nenasilnog rješavanja sukoba. Komunikacija u sklopu Spolne/rodne ravnopravnosti i odgovornog spolnog ponašanja proizlazi iz teme Emocije i komunikacija u vezi. Kao što i sâm naziv govori, cilj ove teme jest raspraviti važnost ravnopravnog komuniciranja u partnerskom/prijateljskom odnosu, protumačiti pojam i važnosti intimnosti u vezi te objasniti vezu između predrasuda prema ženama i njihove diskriminacije $u$ povijesti. Prema ishodima, vidljiva je razlika u pristupu obradi tema povezanih s komunikacijom. Dok međupredmetna tema Zdravlje teži razvijanju kompetencija za odabir primjerenih odnosa i nenasilnom rješavanju sukoba, Spolna/ rodna ravnopravnost i odgovorno spolno ponašanje osvrće se na razvijanje svijesti o važnosti ravnopravnosti u komuniciranju u partnerskom/prijateljskom odnosu, intimnosti i predrasudama (AZOO, 2012).

Odgovorno spolno ponašanje još je jedna zajednička tema u predviđenom razdoblju koja se pronalazi u obama kurikulima. Po pitanju ove teme, Spolna/ rodna ravnopravnost i odgovorno spolno ponašanje naglasak stavlja na razvoj vještina potrebnih za odgovorno spolno ponašanje koje se dotiču pitanja slobode odluke o stupanju u spolne odnose i dogovoru s partnerom o odgovornom 
seksualnom ponašanju. S druge strane, međupredmetna tema Zdravlje u ovom kontekstu teži obradi sadržaja o prevenciji spolno prenosivih bolesti, planiranju obitelji i odgovornog roditeljstva.

Nasilje, još jedna od zajedničkih tema u obama kurikulima, u slučaju međupredmetne teme Zdravlje teži analizi vrsta nasilja, dok se Spolna/rodna ravnopravnost i odgovorno spolno ponašanje usmjerava na spolno/rodno nasilje u vezama kroz opisivanje obilježja nasilne veze, definiranje oblika i posljedica nasilnog ponašanja, seksualnu viktimizaciju, važnost podrške i objašnjavanje veze između nedostatka samopoštovanja i seksualne viktimizacije te prepoznavanje štetnog utjecaja alkohola na odnose u vezi.

Još jedna razlika može se pronaći i u naglasku koji je $u$ Spolnoj/rodnoj ravnopravnosti i odgovornom spolnom ponašanju stavljen na medijski prikaz seksualnosti, uz raspravu o načinima prevladavanja spolnih/rodnih stereotipa, ali i analizi prikaza seksualnosti u pornografiji. Ponovno se može uočiti obrada teme pornografije koja u ovom razdoblju, osim što raspravlja o prikazu muškaraca i žena u kontekstu pornografije, želi raspraviti i o njezinu utjecaj na adolescente. Međupredmetna tema Zdravlje ni u ovom se ciklusu ne dotiče medijskog prikaza, nego (ponovno) predviđa tematiku stresnih situacija i utjecaja zaštitnih čimbenika na mentalno zdravlje.

Ciklus (3. i 4. razred četverogodišnje srednje škole/2. i 3. razred trogodišnje srednje škole)

Posljednji ciklus, onaj koji je namijenjen trećem i četvrtom razredu četverogodišnjih srednjih škola te drugom i trećem razredu trogodišnjih srednjih škola, obilježen je stjecanjem znanja o spolnom i reproduktivnom zdravlju u obama analiziranim kurikulima. Ipak, u samom početku važno je istaknuti razliku koja leži u činjenici da kurikul modula Spolna/rodna ravnopravnost $i$ odgovorno spolno ponašanje staje nakon trećeg razreda srednje škole (u slučaju četverogodišnje srednje škole), dok se međupredmetna tema Zdravlje proteže sve do kraja srednjoškolskog obrazovanja.

Područje tjelesnog zdravlja međupredmetne teme Zdravlje teži preuzimanju brige i odgovornosti učenika za reproduktivno zdravlje te razumijevanju važnosti redovitih liječničkih pregleda. Predviđeno je da će učenici biti sposobni 
opisati načine brige o reproduktivnom zdravlju te moguće rizike od spolno prenosivih bolesti. Također, neki od ishoda predviđaju da će učenici moći opisati odgovorno roditeljstvo putem razlikovanja planirane od neplanirane trudnoće, opisati načine sprječavanja trudnoće, pripremu za trudnoću, dojenje, redovite liječničke preglede i cijepljenja (Odluka o donošenju kurikuluma za međupredmetnu temu Zdravlje za osnovne škole i srednje škole u Republici Hrvatskoj, NN 10/19). Seksualno zdravlje i najčešći seksualni problemi mladih naziv je teme koja u sklopu Spolne/rodne ravnopravnosti i odgovornog spolnog ponašanja adresira problematiku usmjerenu na spolno i reproduktivno zdravlje. Ipak, za razliku od međupredmetne teme Zdravlje, modul predviđa analizu odredbi Deklaracije o seksualnim pravima Svjetske zdravstvene organizacije i definiranje pojma seksualnog zdravlja uz opisivanje najčešćih seksualnih poteškoća u populaciji mladih (AZOO, 2012).

Također, pitanjima obitelji, roditeljstva i braka bave se oba kurikula. Kroz istoimenu temu Spolna/rodna ravnopravnost i odgovorno spolno ponašanje pokušava definirati odgovorno roditeljstvo, usporediti medicinska, religijska i feministička stajališta o prekidu trudnoće te opisati suvremene promjene vezane uz brak. Kao što je ranije navedeno, međupredmetna tema Zdravlje po ovom pitanju dotiče se planirane i neplanirane trudnoće, no ne spominje problematiziranje pobačaja u bilo kojem kontekstu.

Spolna/rodna ravnopravnost i odgovorno spolno ponašanje osim navedenih tema za učenike trećeg razreda srednje škole predviđala je razgovor o seksualnim pravima i stereotipima kroz društvena očekivanja u kontekstu seksualnosti te stigmatizaciju i diskriminaciju seksualnih manjina (AZOO, 2012). Ova problematika ne postoji u kurikulu međupredmetne teme Zdravlje. Kurikul međupredmetne teme Zdravlje u svom petom ciklusu fokus poučavanja usmjerio je na razvoj pozitivne slike o sebi i stvaranju uloge u zajednici, s naglaskom na mogućnosti djelovanja u zajednici. 


\section{Zaključak}

Cilj ovog rada bio je provesti komparativnu analizu kurikula četvrtog modula Zdravstvenog odgoja pod nazivom Spolna/rodna ravnopravnost $i$ odgovorno spolno ponašanje i kurikula međupredmetne teme Zdravlje za osnovne i srednje škole iz perspektive cjelovite seksualne edukacije. Sadržajnom analizom oba kurikula ustvrđene su značajne razlike u predmetu, sadržaju, opsegu i dubini obrade pojedinih tematskih područja. Oba kurikula bave se problematikom komunikacije, vršnjačkog pritiska i reproduktivnim zdravljem. Ipak, svaki kurikul stavlja različit naglasak na ove sadržaje, što rezultira potpunom razlikom u konceptualizaciji kurikula. Kurikul međupredmetne teme Zdravlje u svoj temelj ugradio je tjelesne aspekte seksualnosti uz povremenu obradu komunikacijskih tema koje se izravno ne dotiču komunikacije o seksualnosti. Kurikul teži razvoju pojedinca i zauzimanjem njegove uloge u društvu uz tendenciju izbjegavanja nasilničkih ponašanja. Spolna/rodna ravnopravnost $i$ odgovorno spolno ponašanje u svojoj srži izravno izriče ishode povezane sa seksualnim aspektom ljudskog života, uz povezivanje važnosti razumijevanja seksualnosti za stvaranje prijateljskih i partnerskih veza u zajednici, istovremeno jačajući sliku o sebi. Iz provedene analize evidentna je isključenost rodnih tema u međupredmetnoj temi Zdravlje. Rodne teme više su pozornosti dobile u kurikulu Spolne/rodne ravnopravnosti i odgovornog spolnog ponašanja, što potvrđuje kategorizaciju kurikula u Tip 3 i generaciju teorijski utemeljenih programa. Nedostatak rodnih tema i pitanja pornografije, masturbacije i stereotipa opravdava klasifikaciju kurikula međupredmetne teme Zdravlje u generaciju proširenih programa. Također, nedostatak istih tema ukazuje na problem svrstavanja ovog kurikula u holističke kurikule kojima teži cjelovita seksualna edukacija. Činjenica je da su upravo rodne teme bile sporne pri implementaciji i provedbi četvrtog modula Zdravstvenog odgoja, što je na kraju rezultiralo njihovim ukidanjem. Izbacivanje navedenih sadržaja izravno kurikul međupredmetne teme Zdravlje označava kao kurikul nedostatan za provedbu cjelovite seksualne edukacije kojoj društvo sve više teži. Dakako, kurikul Spolne/rodne ravnopravnosti i odgovornog spolnog ponašanja također je pokazao svoje nedostatke. Ipak, on je sadržajno prilagođeniji načelima i ciljevima cjelovite seksualne edukacije. Najveći doprinos ovog rada leži u činjenici da je rad jedan od rijetkih koji se bavi problematikom kurikula seksualne edukacije na području 
Republike Hrvatske. Komparativna analiza pruža uvid u različitu percepciju važnosti pojedinih tema i njihovih segmenata. Iz provedene analize moguće je zamijetiti koliki naglasak je stavljen na cjelokupnost seksualnosti u modulu Spolna/rodna ravnopravnost i odgovorno spolno ponašanje, dok međupredmetna tema Zdravlje kroz većinsko poučavanje o tjelesnim aspektima seksualnosti šalje poruku da temelj seksualne edukacije leži u poznavanju vlastitog tijela, isključujući poučavanje učenika o rodnim temama, užitku i mnogim drugim temama koje su neophodne za razumijevanje ljudske seksualnosti. Kako bi se postigla cjelovita seksualna edukacija, potrebno je dodatno informirati užu i širu populaciju o njezinim temeljnim načelima i vrijednostima koje se kroz nju promiču. Postavlja se pitanje kada i kako će društvo odrediti koje teme su neophodne kako bi škola, kao sekundarna socijalizacijska okolina zadužena za odgoj i obrazovanje, uz suradnju s obitelji i stručnjacima, mogla stvoriti odgovorne i zdrave ljude koji će se brinuti za svoje i tuđe seksualno zdravlje? 


\section{Literatura}

AZOO (2019). Kurikulum zdravstvenog odgoja. Preuzeto 7. prosinca 2019. s: https:// www.azoo.hr/images/zdravstveni/Kurikulum_ZO.pdf.

European Parliament (EP) (2013). Policies for Sexuality Education in the European Union. Brusseles: European Union.

Federal Centre for Health Education (BZgA) (2010). Standardi spolnog odgoja u Europi. Okvir za kreatore političkih odluka, obrazovne i zdravstvene institucije i stručnjake. Köln: WHO Regional Office for Europe and BzgA.

Štulhofer, A. i Hodžić, A. (2003). Seksualna edukacija u školi: Što je s Hrvatskom? Napredak, 144(1), 40-52.

Odluka o donošenju kurikuluma za međupredmetnu temu Zdravlje za osnovne škole i srednje škole u Republici Hrvatskoj, Narodne novine, 10/19 (2019).

UNESCO (2009a). International Guidelines on Sexuality Education: An evidence informed approach to effective sex, relationships and HIV/STI education. Paris: UNESCO.

UNESCO (2009b). International Technical Guidance on Sexuality Education: An evidence-informed approach for schools, teachers and health educators. Volume 1: The Rationale for Sexuality Education. Paris: UNESCO.

UNESCO (2018). International tehnical guidance on sexuality education: An evidence-informed approach. Paris: UNESCO. 